\title{
Collective Memory and Colloquial Aesthetic Experience. Remarks on the Functions of Digitalized Paintings in Second Life
}

Images

vol. XVII/no. 26

Poznań 2015

ISSN 1731-45OX

A lot of people think that they know Monet's paintings well. The question is: do they? How many of them have looked at his pictures in galleries, museums or even in albums? Monet's paintings became famous for many reasons, but also because of the process of decontextualisation, which changed their aesthetic status and the medium of their dissemination. People started creating copies, reproductions, and duplications of them, and then copies of copies, reproductions of reproductions and duplications of duplications. We can talk about all of these using one common term - images. They became the new "bodies" of the contents represented by copies, reproductions, and duplications. Some of these images were treated as potential or real intertexts or even palimpsests (of the artist, of impressionism, or simply of "beauty"), so they were not only reproduced but also changed. All of these ways of being images began to change in Second Life, a virtual world where users, called avatars, can create their own world, explore existing ones, and interact with other avatars.[1]

Claude Monet's painting Poppies Near Arguentil is present in contemporary culture in many diverse forms. We can still look at the real original painting, but because of the abundance of multiple versions we can observe its diverse presence in (popular) culture: copies, reproductions, and duplications. Paraphrasing the Latin phrase Ars longa, vita brevis, we can now say Art digital, aesthetics colloquial. In popular culture, Monet's painting is popular not only because of its "artistic aura", but also as a natural consequence of the widespread accessibility to works of art, which used to be available to a limited group of people. The concept of "designs" would be an appropriate tool for describing the effects of the new media. For the purposes of this paper, designs could be defined as "semiotic resources in all semiotic modes and combinations of semiotic modes. Designs are means of realizing discourse in the context of a given communication situation, consequently transforming socially constructed knowledge into social interaction. But designs also

[*] Many thanks to Jo-Ann Budzyńska for her suggestions on ways to improve this paper.
[1] http://maps.secondlife.com/secondlife/ Leelight/79/105/621. Second Life was created by Linden Research, Inc. in 2003. Compare with: www. lindenlab.com/about. 
add something new: they realize the communication situation which changes socially constructed knowledge into social (inter)action." [2] The possibility and ease of creating multiple copies, the growth of alternative forms of disseminating visual codes and modes, have led to a change in how works of art are created, presented, represented and viewed. Nowadays, the original oil painting would no longer be seen as "alive" because of the specificity of the canvas as a static medium, at least on the physical level. This means that there are aesthetic, cultural and economic changes that have occurred over time that have changed the way the work has been presented, accessed and seen. One can say that the medium of the painting has changed.

The contents of Monet's paintings are their medium. This is why we can buy reproductions of these paintings, but we can also buy plates, candlesticks, cups, umbrellas, etc. containing depictions of them. Now that paintings can function outside of their physical medium, we can presume that new contexts for using (reading, watching, viewing) Monet's paintings have resulted in new methods, and a new grammar, for understanding and analyzing it. Paintings become images of themselves, disseminated as a symbolic embodiment of the originals in the new media in diverse alternative contexts. The more "bodies" of medium for the paintings we can find, the bigger number of new interpretations and functions we can experience. This process could be referred to as decontextualisation, which reveals paintings as possible elements of intertextual connections with different styles of being of art in culture and in media. From aesthetic (focusing on impressionism) to domestic (a "nice" painting of a cup in the kitchen), from unique aesthetic experience (contact with the original work in a gallery) to its multiple and mediated

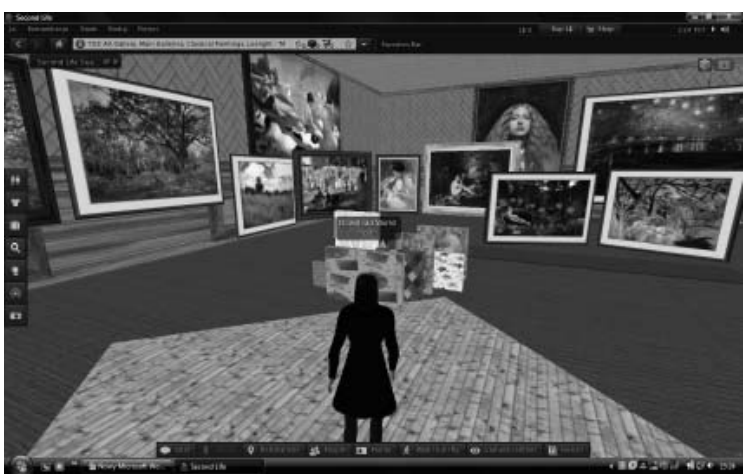
pragmatic use (e.g. digitalized versions in Second Life - illustration 1). The multiple and mediated presence of a painting does not exclude a unique experience but due to limited access to the original, this is not the dominant experience.

In this paper, I will describe the changes in the cultural presence of paintings in Second Life, mainly in the site's TOC Art Gallery.[3] The gallery's architecture is shaped by a structure typical of virtual reality sites. The Gallery part of Second Life consists of two forms of rep-

Il. 1. The digitalized version of Monet's Poppies Near Arguentil in Second Life resentation: digital reality and digitalized reality. Digital reality refers to the structure of the gallery. Digitalized reality refers to the paintings copied from reality in this gallery: there are impressionists on one floor,
[2] G. Kress, T. van Leeuwen, Multimodal Discourse. The Modes and Media of Contemporary Communication, National Council of Teachers of English, London 2001, p. 5.
[3] http://world.secondlife.com/place/ec5f411b-9535e896-1713-ced233a8o8oe 
and pre-Raphaelite paintings on another. But there are some aesthetic "surprises" in every exhibition. Avatars can teleport from one floor to another or they can levitate from one painting to the next. The virtual gallery features a functional interfaces which allow the visitor to interact with art in Second Life while maintaining certain of the conventional and semiotic frames of a physical gallery. As an example of a colloquial aesthetic experience of art, I will use the works of Monet and of other impressionists. Digitalized illustrations of paintings presented in the virtual galleries in Second Life shape ways of thinking about art and about the functions of aesthetic experience.

This paper consists of two main parts: the first describes the process of decontextualisation and its influence on the functioning of painting in virtual reality; the second pertains to the limits of colloquial thinking within the frames of everyday aesthetic experience. The main hypothesis of this paper is that digitalized images of paintings reveal changes in the way we think about art in a world dominated by new media (as exemplified in Second Life). This hypothesis supports the assumption that collective memory is currently dominated by colloquial thinking about art, aesthetics, and beauty. Because of new media, art is becoming programmable, and its contents have start functioning as digits in a database.[4] This emerging relationship between new media and art is changing not only art and aesthetic experience, but also the social and cultural status of the artist. Pierre Lévy is therefore right in saying: "The engineer of worlds will be the major artist of the twenty-first century [...] Software developers, Video game designers, Artists of interactive devices and televirtual systems." [5]

There is an interesting dichotomy between oblivion and memory in the revival processes of diverse cultures disseminated by the users of new media. [6] Collective memory changes own status from officially recognized works to individual, fluent images of art. This means we can find decontextualized collections of works in digital archives and databases. "Condensed" in one virtual, common place, their diversity obliterates their "singularity" ("individuality") symbolically strengthened by the frames of pictures. Oblivion makes decontextualisation possible; memory presents something as fact and can influence, and even distort, one's understanding of well-known images. A database as a prosthesis of collective memory becomes a matrix of potentially new contexts for digitalized works.

Decontextualisation is possible because of the palimpsest nature of the medium, which is able to easily disseminate images. Fluent art means that paintings are shaped by the mechanism of textualization revealing the palimpsest nature of a cultural background of unstable/ fluid boundaries between high art and mass culture, between the cul-

Decontextualisation as a paradigm of fluent art
[4] L. Manovich, Język nowych mediów, trans.

P. Cypryański, WPiA, Warszawa 2006, p. 124.

[5] P. Lévy, Cyberculture, trans. R. Bononno, Universi-

ty of Minnesota Press, Minneapolis 2001, p. 125.
[6] H. Belting, Antropologia obrazu. Szkice do nauki o obrazie, trans. M. Bryl, Universitas, Kraków 2007, p. 86. 
tural centre and its peripheries, between canon and avant-garde.[7] Decontextualisation transcends the original paintings, which can exist as images even without the substantial form of their medium of origin. This transcendence can occur in completely unpredictable circumstances, semiotic environments, and pragmatic ways of understanding. Due to decontextualisation, we can observe alternative, peculiar, ways of disseminating the functioning of art in contemporary life. A "beautiful" cup with an image of Poppies Near Arguentil on it must be beautiful and expensive. People want to participate in exclusive art while drinking tea or coffee, at home or at work. They can transcend their mundane life because they are able to surround themselves with well-known, beautiful, and recognizable art. This is why Monet's images are found among salt and sugar containers on the kitchen counters, as well as on our work desks, right next to our laptops and tablets. These objects form the basic elements ofsocial, cultural, economic, and intellectual decontextualisation. Daily life becomes an open gallery where art is brought closer to real life. Decontextualisation is not a new process in culture; it brings culture to life. The process of decontextualisation is characterized by the spontaneity of the changes in culture which shape it. It is also shaped by people's symbolic and semiotic environment, by the objects they use in daily life. Decontextualisation means that images can work outside of their initial artistic context. They can be dominated by other contexts, like social interaction, as can be observed in Second Life. Decontextualisation is a potential substitution of context which can lead to the loss of an art work's "aura", of which Walter Benjamin wrote.[8] Images are treated as the cohesive and autonomous contents of new contexts, new forms of reading, showing and understanding. Decontextualisation means that, for instance, scientific or scholarly knowledge is "less important" than the typical opinion in the process of reception and perception of art. Images shaped by the mechanism of decontextualisation are seen by people in new ways which are far from the original intent.

The hypertrophy of the aesthetization of daily life can be explained by decontextualisation. The palimpsest nature of this process recalls Genette's theory of palimpsests as a theory of transtextuality. Genette's "the textual transcendence of the text" is defined as "all that sets the text in a relationship, whether obvious or concealed, with other texts." [9] This became in humanities a useful tool for describing diverse forms of cultural practices focused on signs and texts. Genette recognized five types of transtextual relationships: intertextuality, architextuality, paratextuality, hypertextuality, and metatextuality. He explains that every norm of transtextuality is an aspect of every textuality.[10]

[7] Ch. Gere, Digital Culture, Reaktion Books, London 2008 , p. 101.

[8] G. Kress, T. van Leeuwen, op. cit., p. 7.
[9] G. Genette, Palimpsests: Literature in the Second Degree, University of Nebraska Press, Nebraska 1997, p. 1.

[10] Ibid., pp. 327-328. 
Genette, in using the word "palimpsest", took the characteristics of physical writing into the semantic level. Palimpsest in this sense refers to texts which have been re-interpreted and changed many times over. In this context, Monet's image presented in the virtual gallery is a hypotext in relation with the hypertextual environment. Links which refer to the author, title, and the price of the work are paratexts. Additional commentaries, access to forums, additional information, interface, and instructions for the avatar are metatexts of the image. In this context, what seems to be a naïve or simplistic exhibition of works of art in Second Life is revealed to be full of intertextual networks of tastes, connotations and associations. If we accept the premise that basic rationality in Second Life is shaped by colloquial thinking, we can say that intertextuality is one of the most influential features in this method of perceiving art.

"Today, we seem to suffer from a hypertrophy of memory, not history." [11] Borrowing this quote to describe a completely different context, we can metaphorically say that nowadays it is possible to observe a hypertrophy of collective memory, collective imagination, and the collective transposition of art because of the influence of new media. What does "influence" mean? We can digitalize - which also means "change", "shape", "copy", "disseminate" - images to reflect our contemporary aesthetic needs, articulated easily and conveniently. Contemporary forms of the decontextualisation of art show more than we might expect. They are palimpsests of thinking about art as tradition, as an example of the past, as a result of the dialectics between knowledge and ignorance. Changes in the functioning of art in contemporary culture reflect changes in humanity in history. New media, the Internet, and Second Life confirm that today we live in a hegemony of colloquial thinking because, for the first time, this form of rationality is fixed in such diverse and multi-modal discursive ways.

To sum up, I would like to say that decontextualisation is a frame for collective memory concerned with art in a general sense. Colloquial thinking as a rationality for daily aesthetic experience shows that thinking about art does not have to be supported by a "proper" (adequate) cultural context. The need for beauty (even when this "beauty" is defined by tradition, even when this "beauty" is described in colloquial terms) reveals an typical and common idea of existence in art. Thus, we can understand why impressionists are presented next to Renaissance paintings; why the Mona Lisa, surrounded by paintings of impressionists and postimpressionists (il. 2), can drink digital tea from a digital cup in Second Life; why her neighbours are the woman and the man from Degas's painting Absynt.[12] Colloquial aesthetic experience does not have to function as a cohesive, competent, critical

[11] A. Huyssen, Present Pasts: Urban Palimpsests and the Politics of Memory, Stanford University Press, Stanford 2003, p. 3 .
[12] http://maps.secondlife.com/secondlife/ Leelight/79/105/621: TOC Art. Gallery, Main Galleries, Classical Paintings, Leelight. 


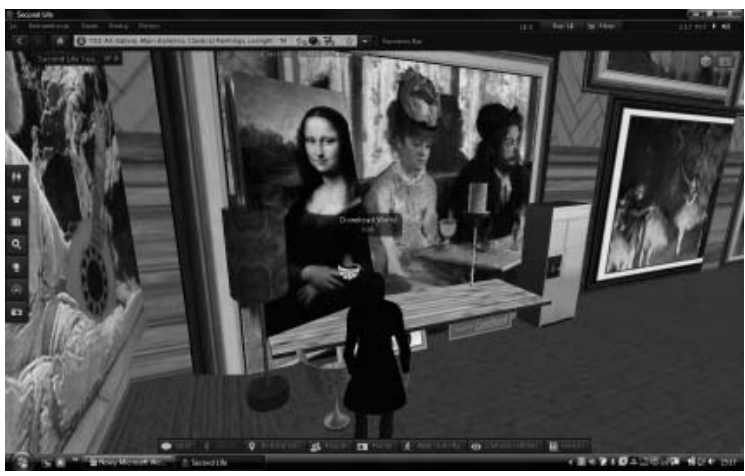

attitude of the people who participate in art in diverse ways. One can assume that the same people who like visiting virtual galleries in Second Life would use ringtones borrowed from Vivaldi or Mozart simply because "this music is so moving and generally well-known that I like it." Decontextualisation implies collective memory about art as a typical aesthetic sensibility ("typical" denoting a neutral rather than a negative connotation). This means that colloquial taste is shaped by the cultural in-

Il. 2. Mona Lisa with Degas's Absynt in Second Life

Features of daily aesthetic experience dustry, strengthened by the repetition of mechanisms, subjects, motifs, gestures, sounds, signs, and symbols. We can treat decontextualisation as the aesthetic equivalent of the social practice of participation in art.

Avatars in Second Life can fly, or discuss or look at paintings. As part of Second Life, TOC Art Gallery is shaped by the same rules as other virtual realms in Second Life. An avatar standing in front of Monet's painting can read the title, look at another painting, levitate to other floors of the gallery, or look at multiple paintings at the same time. Every floor in this virtual gallery looks like a store where the size of the art collection is more important than the form of its presentation. This relation strengthens the interaction between the user (through his avatar) and the image of a particular painting. As the subjects of communication in the exhibition, Avatars can "touch" the paintings. All of these images are made accessible in a virtual space, although the authors of the gallery present the paintings in a peculiar order. There are thematic floors, so for example, impressionists are exhibited on the same floor as classical paintings.[13] The paintings could also be accessed using the names of the authors or the titles of the works. Every floor of this virtual gallery is full of well-known paintings, so it represents the general or collective imagination/idea about art, and the public's typical aesthetic experience. There are also other virtual galleries in Second Life.

The digitalized versions of Monet's works in Second Life take the place of the originals, functioning as a medium of art in the absence of the real paintings. The digitalized paintings also become the typical medium with which the user comes in contact in contemporary culture. They have come to represent the accepted method in the mode of perception and reception of art.[14] Avatars in the virtual picture gallery in Second Life can "look" at impressionists' works, which are exhibited right next to the digitalized Renaissance paintings; Monet's paintings are next to Da Vinci's works. There is no common idea, no common topic which could make this virtual exhibit cohesive or coherent. It
[13] <http://world.secondlife.com/place/ec5f411b9535-e896-1713-ced233a8o8oe>.
[14] H. Belting, op. cit., pp. 6-7. 
looks rather like a storehouse. Many digitalized paintings are presented in the same virtual place frequented by avatars. On the one hand, users want their avatars to behave as they would in real life, but, on the other hand, this virtual world is "drawn", i.e., digitalized, where the reproduced paintings function in a virtual, digital space and where the physical limitations of the real world do not exist. Second Life is built on images - digital (created in virtual reality), and digitalized (taken from real world to virtual). Almost every image demands something from the viewers - "wants them to do something (come closer, stay at a distance) or to form a pseudo-social bond of a particular kind with the represented participant"[15] or the(re)presented object. According to Kress and van Leeuwen, we can say the same thing about Second Life, that "images define to some extent who the viewer is (e.g. male, inferior to the represented participant, etc.), and in that way exclude other viewers", [16] other avatars, other users. Second Life is a semiotic place, which means that there are signs, and signs of signs in places, because this realm of human experience does not have to exist in one space. Places mean places of interaction among users and their computers. People can interact in the same places being physically in different spaces. Second Life is a semiotic place for people, for their cultural texts, and for images. Avatars and images are in the same place, but they refer to completely different designates. Avatars are the images of users, digitalized paintings are the images of real disseminated sources. Avatars and digitalized paintings are the elements of the image of an art gallery. There are approximately three dimensions of mediation: first - digitalized subjects (avatars) and objects (paintings), second digitalized signs (like paintings or avatars) in virtual reality ("drawn" art gallery), third - interaction and communication in Second Life (avatars can interact, "look at" images, change levels by levitating.) These three dimensions are examples of the decontextualisation of art. The presence of this mechanism is much more visible when we observe a strong detachment (separation) of space from the place of interaction.

These dimensions contain certain features of virtual images as represented in Second Life: the dissemination of the relation between the original work and its duplicates (which are sometimes transformed); the lack of a material basis for the image (only the digital source is available, which is shaped by socio-cultural modes of perception); and the possibility of open access through mobile media, changing the social and aesthetic status of the images. The enjoyment of a virtual image, therefore, relies more on when you view it rather than on where you view it. The deconstruction of a programmable image, its perception or perspective, consequently depends on colloquial thinking, on the transformation of differences between art and life, between fiction and 
reality.[17] The virtual images are now the embodiment of the originals and now function as their medium.[18]

The galleries in Second Life also present art created only in Second Life.[19] There are artists from the real world, for example Patrick Moya, who create "private" galleries to promote their work in the virtual world.[20] The need to experience art exists in Second Life, although this means that this need is often shaped by the colloquial frames of aesthetic experience. On his virtual island, Moya presents his own personal digitalized works - it does not represent a wider, public artistic perspective. But the TOC Art Gallery, despite its attempts to recall a real gallery whose narration is ordered and structured, reveals a typical taste - a daily aesthetic experience. The colloquial imagination about art can fulfil almost every need for aesthetic experience. Avatars can look at "nice", well-known images, and can thus "participate" in art which represents the collective memory of paintings and their social and cultural roles and functions. I cannot say, however, whether this form of experiencing of art is less important than going to a physical art gallery. Second Life is real, although the status of the visitor in the gallery and that of the artistic work are different from what we were used to. There are mixed levels of mediation of aesthetic experience: the avatar, a virtual image of the user, looking at virtual images of paintings in a virtual world which is an image or imagined version of a gallery. In general, three versions of images interact in a decontextualised semiotic place, where time prevails over space, where the logic of the image (the digitalized painting) prevails over the logic of representation (the order of reference presented in the frame of a painting).[21] The image of the gallery functions as an actual gallery with regards to its social and cultural status in Second Life. Decontextualisation means that the images are presented in an arbitrary way, that they are treated as tools in a virtual game, that they can be used as objects of interaction with avatars, that they can function as representations of the paintings gathered in one store to reflect typical and colloquial thinking about art.

The theoretical approach regarding common thinking proposed by Clifford Geertz is particularly relevant in the following context. Commonness, according to Geertz, is a weakly integrated cultural

[17] Inspiration is taken from individual user's experience and from: J. Ludwiński, "Sztuka w epoce postartystycznej”, [in:] Refleksja konceptualna w sztuce polskiej. Doświadczenia dyskursu: 1965-1975, ed. P. Polit, P. Woźniakiewicz, CSW Zamek Ujazdowski, Warszawa 200o, pp. 106-118. Quoted by: E. Wójtowicz, "W stronę antymaterii. Sztuka Internetu wobec refleksji teoretycznej”, [in:] Perspektywy badań nad kultura, ed. R.W. Kluszczyński, A. Zeidler-Janiszewska, Wydawnictwo UŁ, Łódź 2008, p. 201.

[18] H. Belting, op. cit., p. 22.

[19] There are a lot of genres of art in new media which function between digitalized art and digital art:
Bio art., Database Art, Digital Activism, Digital Animation, Digital Community (Social Network), Digital Graphics, Digital Performance, Game Art, Glitch Art, Installation, Net Art, Robotics, Transmedia Story Telling. More information you can find at: <https:// www.digitalartarchive.at/nc/home.html $>$. [20] <http://maps.secondlife.com/secondlife/ Moya/135/128/23>.

[21] P. Virilio, "Maszyna widzenia", [in:] Widzieć, myśleć, być. Technologie mediów, ed. A. Gwóźdź, Universitas, Kraków 2001, p. 45. 
system, though it is based on the same foundations as other systems: "on the awareness of its value and the rights of those that remain in it. Here, as everywhere, everything is just as we made them." [22]

Commonness (common sense) is the daily experience of culture. In Second Life, commonness seems to be the centre of cultural style as it has universal prevalence. "The common experience of culture is always the first contact with models of behaviour and responses; however, commonness may take the form of either the cultural elite or the masses." [23] Commonness is a function of the experience of signs, which may not entirely be conscious, and shapes us as cultural participants. Commonness is a potential presentation, an actual attempt at comprehension, and a description of varied stimuli and information which make up everyday life.[24] While this is true of modern times, one can also assume that similar functions of commonality also existed earlier.

In research on common thinking and common knowledge, there is no singular cognitive model or theoretical construction. This may be due to the fact that the concept of common thinking disallows the construction of an intersubjective tool for description. Thus, the interpretation of common thinking depends on the field of knowledge which an academic researcher possesses: anthropological, literary, or philosophical. The methodology attempts to keep up with varied, changing, and unintegrated descriptions of the world in which the experience and knowledge of reality are relative to a syntagmatic contiguity which rejects metastructure, treating knowledge not as the result of thought, but as the result of experience. One can then claim, paraphrasing Clifford Geertz, [25] that in common thinking the role of objectivity is taken over by obviousness - the obviousness of experience.

Commonness is a process covering sense and meaning emerging from daily experience, common sense, official discourse, popular culture, education, or television. Colloquial thinking includes elements that are not always seen as traditional.

Obviousness in commonness takes the place of objectivity. The typical aesthetic experience explains why we know Monet's images, but we do not remember the author's name or the title of his paintings, although we can say that we like them.

Another important feature of common sense is what Geertz would refer to as practicality, which functions as a substitute for critical thinking. The virtual art gallery can be compared to a neighbourhood store where one feels more at home than in a supermarket. In Second Life, the visitor can get much closer to the art than they would be able to in the real world.

[22] C. Geertz, Wiedza lokalna. Dalsze eseje z zakresu antropologii interpretatywnej, trans. D. Wolska, Wydawnictwo UJ, Kraków 2005, p. 84.

[23] Z. Kloch, Odmiany dyskursu. Semiotyka życia publicznego w Polsce po 1989 roku, Wydawnictwo UWr, Wrocław 2006, p. 15.
[24] R. Sulima, Antropologia codzienności, Wydawnictwo UJ, Kraków 2000, p. 4.

[25] C. Geertz, op. cit., p. 83. 
The next feature of common sense is called "transparency" (another term inspired by Geertz), which is treated as an intellectual prosthesis of interpretation. The user knows what they want to know and sometimes this is enough. Other users have a lot in common with each other because they know the same texts, contents and requirements. Daily aesthetic experience seems to be similar because many people have almost the same artistic expectations and almost identical intellectual frames of perception.

Unpredictability (non-methodology) is another feature of common sense (taken from Geertz's conception) which pertains to an alternative frame of knowledge. The avatar, which is the user's interface in Second Life, does not have to be cohesive and consequent in its experience of art. It does not have any internal aesthetic, axiological, or cognitive conflicts. It likes what it likes at this moment, in this particular place because of some typical well-known images transmitted in the media. Due to a lack of predictability, we can think about colloquial thinking as a cognitive matrix which makes art fluent.

Accessibility as a final feature of common sense means that almost every user can be a specialist in the conceptualization and creation of art. This is why almost everyone can create their own art gallery in Second Life and almost everyone can transform well-known paintings into images which reveal the user's sensibility or irony. The digitalized Mona Lisa drinks digital tea in Second Life. Simple associations reveal irony and a distance to the subject, as well as the user's technological knowledge of the virtual gallery. The levitating avatar in the gallery confirms changes in the ontological status of the image, but also in art in general. If I can levitate in an art gallery, it means that I am not in a gallery, but that I am playing in the participation of art. For the typical virtual spectator, Degas and Da Vinci would be similar or comparable because Mona Lisa can drink tea with characters taken from Degas' painting. This aesthetic presumption supports the presence of a constant overlapping of cultural centres and peripheries in Second Life.

Decontextualisation is a natural consequence of the influence of colloquial thinking in art. All of the above-mentioned features become signs of decontextualisation in daily life, not only in Second Life.

\section{Conclusion}

In treating decontextualisation as a paradigm for fluent art, revealing the features of daily aesthetic experience, [26] I wanted to show that digitalized images of paintings reveal changes in thinking about art in a world dominated by the new media.[27] Second Life is an alternative dimension of reality. Nowadays aesthetic experience is not only rooted in art, but also in technology shaped by the process of semiosis. We can assume that the triangle: art - technology - semiosis means that collective memory is dominated by colloquial thinking.

[26] R. Bubner, Doświadczenie estetyczne, trans.

K. Krzemieniowa, Oficyna Naukowa, Warszawa 2005, pp. 178-179.
[27] M. Hendrykowski, Semiotyka ruchomych obrazów, Wydawnictwo Naukowe UAM, Poznań 2014, pp. 216-231. 
With the rise of the internet, for the first time in history, commonness is set and spread in such diverse and multimodal ways. The ability to edit almost every statement made by a user erases the differences between critical knowledge and common sense, between the cultural centre and the periphery, between individuals and tradition. The last opposition means that individuals can disseminate new descriptions, alternative (whether banal or original) interpretations, statements and utterances. This is why the avant-garde on the Internet comes alive - individuals confront tradition, even when their rationality is shaped by colloquial thinking.

Second Life exists in a cultural, social, political, religious, and economic context. The mechanisms which are typical for popular culture (inter)act in virtual worlds. [28] The unification of values and behaviour, the standardization of representations, and the multiplication of well-known signs, symbols, and images make Second Life similar to reality, and at the same time, serve as an alternative to it.[29] Second Life creates peculiar forms of cognitive and aesthetic experiences. This means that changes in the understanding of art reveal a general evolution of the contemporary need for transgression, transcendence, and communication. [30] If collective memory is shaped by colloquial thinking we are able to observe the dialectics between commemoration and oblivion[31] not only in art, but also in humanity's signs and symbols.

Up to this point, I have not used the word "simulacrum" (understood as a sign which has lost its own referential identity, but has not lost its functional and interactive potential) because I wanted to show the peculiarity of the influence of Second Life on art and aesthetic experience in the context of the evolution of the cultural status of collective memory. On the one hand, simulacrum as a popular category imposes semantic meanings which dominate and overwhelm subtler aspects of new theoretical realms which are just as important. On the other hand, this term can "work" in alternative contexts. This means that a simulacrum also functions as an element of decontextualisation. Second Life is full of these kinds of signs, but it is not the sum of them. If we want to observe changes in contemporary thinking about art and about culture, we must do more research focused on Second Life because in some ways this virtual reality could become the future of daily life.

[28] M. Kaźmierczak, Auschwitz w internecie. Przedstawienia Holokaustu w kulturze popularnej, Wydawnictwo Naukowe UAM, Poznań 2012.

[29] P. Levinson, Nowe nowe media, trans.

M. Zawadzka, Wydawnictwo WAM, Kraków 2010,

pp. 222-227.
[30] S. Cubitt, Digital Aesthetics, SAGE Publications, London 1998, pp. 116-122.

[31] M. Augé, Formy zapomnienia, trans. A. Turczyn, Universitas, Kraków 2009; M. Augé, Nie-miejsca. Wprowadzenie do antropologii hipernowoczesności, trans. R. Chymkowski, intro. W.J. Burszta, Wydawnictwo Naukowe PWN, Warszawa 2010. 